\title{
Тримодальна органозберігаюча терапія в сучасному алгоритмі лікування первинного низькодиференційованого м'язово-інвазивного раку сечового міхура
}

\author{
П. Г. Яковлев
}

Національний медичний університет імені О. О. Богомольця, м. Київ

\section{A three-mode organ-preserving therapy in modern algorithm of treatment of primary low-differentiated musculo-invasive cancer of the bladder}

\author{
P. G. Yakovlev
}

Bogomolets National Medical University, Kyiv

\section{Реферат}

Мета. Визначити сучасне місце тримодальної органозберігаючої терапії (ТМТ) в лікуванні первинного низькодиференційованого (G3) раку сечового міхура (PCM).

Матеріали і методи. Проаналізовані ретроспективно дані історій хвороб 346 пацієнтів 3 первинним G3 PCM, оперованих за 2004 - 2017 рр., а саме клінічна стадія РСМ; методи лікування: хірургічний (радикальна цистектомія/резекція), дистанційна променева терапія (ДПТ), поліхіміотерапія (ПХТ); виживаність. 3 причини тяжкої коморбідності 13 хворим, крім біопсії сечового міхура, подальшого хірургічного лікування не проводили. Цих хворих з аналізу ми виключили. Результати. Органозберігаюча операція виконана 224 (67\%) хворим. Загальна смертність становила 63\%. Післяопераційну терапію (ДПТ або ПХТ) отримали 54 (16,2\%) хворих, 3 них 44 (81,5\%) - ДПТ, 10 (18,5\%) - ПХТ. Жодному пацієнту не проводили в комбінації ПХТ та ДПТ. Загальна смертність хворих, що отримали ДПТ або ПХТ, становила 80\%, середня тривалість дожиття - 17 та 8 міс відповідно.

Висновки. Органозберігаюча хірургічна тактика в сучасному лікуванні первинного G3 PCM займає вагоме місце: 67\% усіх хворих були оперовані в обсязі резекції. ТМТ на даний час не застосовують в лікуванні G3 PCM. Післяопераційна ПХТ або ДПТ проведена 16,2\% хворих в монорежимі здебільшого з паліативною метою, що не сприяло тривалій виживаності (смертність становила 80\%).

Ключові слова: рак сечового міхура; м’язово-інвазивний рак; тримодальна терапія; резекція; виживаність.

\section{Abstract}

Objective. To determine a modern position of a three-mode organ-preserving therapy (THMTH) in treatment of primary lowdifferentiated (G3) cancer of thebladder (BC).

Materials and methods. Retrospective data from medical cards were analyzed in 346 patients, suffering primary G3 cancer of the bladder, who were operated in $2004-2017$ yrs, Among them there were the bladder cancer clinical stage, procedures of treatment - surgical (radical cystectomy/resection), distant radiation therapy (DRTH), polychemotherapy (PCHTH), and survival of the patients. In 13 patients further surgical treatment was not performed, their treatment was restricted by the bladder biopsy because of severe comorbidity presented. These patients were excluded from the analysis.

Results. Organ-preserving operation was conducted in 224 (67\%) patients. Total mortality have constituted 63\%. Postoperative therapy (DRTH or PCHTH) have obtained 54 (16.2\%) patients, of them 44 (81.5\%) - DRTH, 10 (18.5\%) - PCHTH. Combination of PCHTH and DRTH was not used. General mortality in the patients, who obtained DRTH or PCHTH, have constituted 80\%, average duration of survival -17 and 8 mo, accordingly.

Conclusion. Organ-preserving surgical tactics in modern treatment of primary G3 cancer of the bladder occupies prominent position: $67 \%$ of all the patients were operated, using resection. Postoperative PCHTH or DRTH was conducted in $16.2 \%$ patients in monoregime mainly with palliative objective, what did not promoted a durable survival (mortality have constituted $80 \%$ ).

Keywords: the bladder cancer; musculo-invasive cancer; three-mode therapy; resection; survival.

Стандартом лікування м'язово-інвазивного раку сечового міхура (РСМ) є радикальна цистектомія (РЦЕ) з тазовою лімфодисекцією [1]. Проте такий вид хірургічного втручання має ряд недоліків, зокрема, високі післяопераційна захворюваність, смертність та негативний вплив на якість життя [2]. Виживаність після великих травматичних втручань, до яких належить РЦЕ, також залежить від віку хворого, загального соматичного стану та коморбідності [3]. Згідно з Національним канцер-реєстром України пік захворюваності на РСМ припадає на віковий проміжок 80
- 84 роки - для чоловіків та 75 - 79 років - для жінок [4]. Альтернативним сучасним підходом до лікування м'язовоінвазивного РСМ вважають тримодальну органозберігаючу терапію (ТМТ) [5], яка включає резекцію сечового міхура, дистанційну променеву терапію (ДПТ) на ділянку оперованого міхура і малий таз та поліхіміотерапію (ПХТ).

Мета дослідження: визначити сучасне місце та перспективи застосування ТМТ у лікуванні первинного низькодиференційованого РСМ в умовах онкоурологічного стаціонару м. Києва. 


\section{Матеріали і методи дослідження}

Проведено ретроспективний аналіз даних історій хвороб 346 пацієнтів з первинним низькодиференційованим (G3) PCM, яким за 2004 - 2017 рр. проведено радикальне лікування в умовах відділення урології Київського міського клінічного онкологічного центру та кафедри онкології Національного медичного університету імені О. О. Богомольця. Усім хворим як перший етап лікування виконали біопсію пухлини сечового міхура з метою визначення ступеня клітинної атипії, поширеності ураження сечового міхура пухлиною та показань до подальшого хірургічного лікування. За умови ендоскопічної резектабельності під час біопсії виконували радикальне ендоскопічне видалення пухлини в межах здорових тканин сечового міхура. 3 причини тяжкої коморбідності 13 хворим, окрім біопсії сечового міхура, подальшого хірургічного лікування не проводили. Ці хворі з аналізу були виключені. Показання до ад’ювантної терапії (ДПТ та/або ПХТ) після органозберігаючого хірургічного лікування або передопераційного лікування за умови планування відкритої операції на сечовому міхурі визначали на мультидисциплінарному онкологічному консиліумі за участі онкоуролога, хіміотерапевта та променевого терапевта. У даному дослідженні проаналізовані та статистично опрацьовані такі дані хворих із G3 PCM, як клінічна стадія раку; застосовані методи радикального лікування: хірургічний (РЦЕ або органозберігаюча операція) та ДПТ, ПХТ; виживаність хворих після лікування. Стадію РСМ визначали відповідно до клінічної класифікації АJCC TNM Classification (7th ed., 2010). Математично дані виживаності та поширеності видів лікування опрацьовували за допомогою стандартного пакета Microsoft Excel 2010 та XLSTAT, обчислюючи середню величину зі стандартним відхиленням (M $\pm \mathrm{SD})$.

\section{Результати}

За термін спостереження оперовано 333 хворих $з$ первинним низькодиференційованим (G3) РCM. Середній термін спостереження за хворими становив 93 міс (від 1 до 226 міс). Чоловіків було 276 (83\%), середній вік яких на початку хвороби становив $(62 \pm 4,5)$ року. До моменту проведення цього дослідження померли 211 (63\%) хворих.

Усі 24 (7,2\%) хворих із G3 РСМ І стадії були оперовані в обсязі органозберігаючої операції - трансуретральної резекції (ТУР) або відкритої резекції сечового міхура. Жодному пацієнту з первинним рT1G3 РСМ РЦЕ не було виконано. В післяопераційному періоді хворі із І стадією РСМ отримували внутрішньоміхурову BCG-терапію.
Із 309 хворих із м'язово-інвазивним раком рТ2-4 стадії РЦЕ виконали 109 (35,3\%), решті хворих - органозберігаючу операцію (див. маблицю).

За нашими даними, загальна п'ятирічна виживаність хворих із G3 PCM II, III та IV стадій після радикального хірургічного лікування в обсязі РЦЕ становила 43, 37 та 10\% відповідно, після органозберігаючого лікування (резекція + ТУР) у хворих з РСM I, II, III та IV стадій - 83, 58, 42 та 40\% відповідно [6].

ДПТ та ПХТ отримали загалом 54 із 333 хворих із G3 РСМ після хірургічного лікування.

ДПТ на оперований сечовий міхур була проведена 44 хворим (13,2\% від усіх оперованих хворих та 19,6\% від усіх хворих, яким проведено органозберігаюче лікування). Розподіл хворих за стадіями раку (I, II, III, IV) був таким: 2, 18, 18 та 6 відповідно. Дозу променевої терапії, яку обраховували індивідуально для кожного хворого на підставі комп'ютерного моделювання зони опромінення, варіювала від 20 до 40 Гр на ділянку малого таза та від 37,4 до 53 Гр на оперований сечовий міхур. Лікування проводили на апараті з лінійним прискорювачем Siemens Oncor Impression Plus та розпочинали не раніше місяця від виконаної операції. Із 44 хворих, що отримали комбіновану терапію (органозберігаюча операція + ДПТ), 9 були живі на момент проведення цього дослідження, середній термін спостереження - 69 міс (від 40 до 135 міс). У цих пацієнтів була I та II стадії РСМ. Середній термін дожиття решти 35 хворих, що померли від прогресії хвороби, становив 17 міс (від 1 до 87 міс). У пацієнтів, що померли, були II - IV стадії хвороби.

Післяопераційна ПХТ була проведена 10 (4,5\%) пацієнтам після органозберігаючої операції, ІІ стадію мали 6, III 4 пацієнти. Післяопераційне хіміотерапевтичне лікування проводили за схемами GC (гемцитабін 2000 - 4000 мг на курс, карбоплатин 450 - 600 мг на курс), MVAC (метотрексат 80 - 100 мг на курс, вінбластин 20 мг, адріабластин 80 мг, карбоплатин 600 мг на курс) або в інших комбінаціях хіміотерапевтичних препаратів в індивідуально підібраних дозах у залежності від антропометричних даних та клінічної ситуації. На момент проведення даного дослідження 2 з 10 хворих були живі, середній термін спостереження - 79 міс (від 47 до 125 міс). Канцерспецифічна виживаність інших 8 хворих, що померли, становила 7,9 міс (від 2,4 до 20,8 міс). Жодному пацієнту передопераційної ПХТ не проводили.

Підсумувавши показники виживаності хворих із G3 PCM, яких оперували в обсязі резекції сечового міхура та які отримали післяопераційне лікування (ДПТ або ПХТ),

\begin{tabular}{|c|c|c|c|c|c|}
\hline \multirow{3}{*}{ Метод хірургічного лікування } & від & рюва & году & о лік & \\
\hline & \multicolumn{4}{|c|}{ Стадія } & \multirow{2}{*}{ Усього } \\
\hline & 1 & II & III & IV & \\
\hline ТУР сечового міхура & 18 & 62 & 36 & 23 & 139 \\
\hline Резекція сечового міхура & 6 & 41 & 33 & 5 & 85 \\
\hline РЦЕ & - & 46 & 33 & 30 & 109 \\
\hline Загалом ... & 24 & 149 & 102 & 58 & 333 \\
\hline
\end{tabular}


ми визначили, що смертність становила 80\% (померли 43 хворих 3 54, що отримали ад'ювантне лікування, середня тривалість дожиття 17 міс - після ДПТ та 7,9 міс - після ПХТ). Якщо порівняти цей показник із загальною смертністю у групі хворих із G3 PCM (63\%), можна стверджувати, що післяопераційну ДПТ або ПХТ проводили суто з паліативною метою, о не сприяло покращенню виживаності.

Важливо, що жоден із хворих із низькодиференційованим РСМ, оперованих в обсязі органозберігаючого втручання, не отримав ДПТ і ПХТ разом. Таким чином, тримодальну органозберігаючу терапію при низькодиференційованому РСМ поки не застосовують.

\section{Обговорення}

На сьогодні мультимодальну (тримодальну) терапію при м'язово-інвазивному РСМ розглядають як дієву альтернативу РЦЕ у хворих, які або відмовляються від РЦЕ, або з огляду на соматичний стан не зможуть перенести такий обсяг хірургічного втручання, або відповідають вимогам до виконання органозберігаючої операції, а саме не мають ураження шийки сечового міхура, ураження сечового міхура локалізоване, немає поєднаної carcinoma in situ, та розуміють і сприймають ризики такого лікувального підходу [5, 7]. Мета мультимодальної терапії - зберегти сечовий міхур та забезпечити прийнятну якість життя хворого без погіршення онкологічних результатів лікування [1]. У разі комбінації цих трьох лікувальних прийомів збереження сечового міхура через 10 років від початку лікування констатують у 79\% хворих, а десятирічна канцерспецифічна виживаність становить 76\% [8]. Зміст поєднання резекції та ДПТ полягає в досягненні локального контролю над пухлиною як у сечовому міхурі, так і в прилеглих лімфатичних вузлах [1]. Додавання системної ПХТ або інших радіосенсибілізаторів має на меті підсилення дії ДПТ та вплив на мікрометастази, що відбувається за рахунок введення платиновмісних хіміопрепаратів [1]. Варіантами органозберігаючого лікування можуть бути, окрім означеної ТМТ, ТУР сечового міхура в монотерапії [9], ДПТ або ПХТ у монорежимі, комбінація резекції з ДПТ або ПХТ, а також поєднана хіміо- і радіотерапія, зокрема у пацієнтів похилого віку [10]. Хоча РЦЕ є стандартом лікування м'язово-інвазивного РСМ [11], показники ранньої післяопераційної захворюваності, смертності та загальної виживаності змушують розглядати альтернативні варіанти лікування. На сьогодні 90-денна післяопераційна смертність у разі виконання РЦЕ становить 2,9\% [2, 12, 13], загальна виживаність через 2 та 5 років після РЦЕ - 71,5 та 50 - 66\% відповідно [13 - 15]. За нашими даними [6], у разі проведення хірургічного органозберігаючого лікування (відкрита або трансуретральна резекція сечового міхура) в режимі монотерапії п'ятирічна загальна виживаність у хворих із I, II, III та IV стадіями становить 83, 58, 42 та 40\% відповідно та є достатньо високою.

Даним дослідженням ми виявили, що післяопераційна ДПТ та ПХТ, яку провели всього 16,2\% оперованих хворих, сприяла довготривалій виживаності лише 9 із 44 хворих після ДПТ та 2 із 10 хворих після ПХТ. Післяопераційну ДПТ та ПХТ не застосовували разом у жодного хворого в нашій вибірці. Це підкреслює необхідність розроблення алгоритмів оптимального використання наявних терапевтичних можливостей з метою впровадження тримодальної органозберігаючої терапії у хворих із низькодиференційованим м'язово-інвазивним РСМ для досягнення кращих результатів лікування та якості життя.

\section{Висновки}

1. Органозберігаюча хірургічна тактика в сучасному лікуванні первинного низькодиференційованого РСМ займає вагоме місце. Двом третинам (67\%) усіх оперованих хворих із G3 PCM було виконано втручання в обсязі трансуретральної або відкритої резекції сечового міхура, решті (33\%) пацієнтів - РЦЕ.

2. Тримодальну органозберігаючу терапію (резекція, ДПТ та ПХТ) поки не застосовують для лікування хворих iз G3 PCM.

3. Післяопераційна ДПТ проведена 19,6\% хворих після резекції сечового міхура, ПХТ - 4,5\% хворих, і жодного разу обидва методи не застосовували разом. У $80 \%$ хворих ад'ювантна терапія була палітивною та не сприяла тривалій виживаності.

\section{Підтвердження}

Фінансування. Джерелом фінансування публікації статті $є$ кошти іiі автора.

Конфлікт інтересів. Автор інформує про відсутність потенційного та явного конфлікту інтересів, пов'язаних із цим рукописом.

\section{References}

1. Witjes JA, Bruins M, Cathomas R, Compérat E, Cowan NC, Gakis G, et al. Muscle-invasive and Metastatic Bladder Cancer. EAU Guidelines. Edn. presented at the EAU Annual Congress Barcelona.: EAU Guidelines Office, Arnhem, The Netherlands.; 2019. Available from : https://uroweb. org/guideline/bladder-cancer-muscle-invasive-and-metastatic/\#7_8.

2. Shabsigh A, Korets R, Vora KC, Brooks CM, Cronin AM, Savage C, et al. Defining early morbidity of radical cystectomy for patients with bladder cancer using a standardized reporting methodology. Eur Urol. 2009;55(1):164-74. doi: 10.1016/j.eururo.2008.07.031.

3. Parikh N, Sharma P. Frailty as a prognostic indicator in the radical cystectomy population: a review. Int Urol Nephrol. 2019;51(8):1281-1290. doi: 10.1007/s11255-019-02189-Z.

4. Fedorenko ZP, Michailovich YY, Goulak LO, Gorokh YL, Ryzhov AY, Soumkina OV, et al. Cancer in Ukraine 2017 - 2018. Incidence, mortality, activities of oncological service. In: Bulletin of National Cancer registry of Ukraine. Kyiv: National Cancer Institute of Ukraine; 2019. Available from : http://www.ncru.inf.ua/publications/BULL_20/index_e.htm.

5. Ploussard G, Daneshmand S, Efstathiou JA, Herr HW, James ND, Rödel $\mathrm{CM}$, et al. Critical analysis of bladder sparing with trimodal therapy in muscle-invasive bladder cancer: a systematic review. Eur Urol. 2014;66(1):120-37. doi: 10.1016/j.eururo.2014.02.038.

6. Yakovlev PG, Klyushin DA, Vereshchako RI. Bladder sparing surgery in high-grade bladder cancer. Exp Oncol. 2019;41(2):160-5. doi: 10.32471/ exp-oncology.2312-8852.vol-41-no-2.13207.

7. Song YP, McWilliam A, Hoskin PJ, Choudhury A. Organ preservation in bladder cancer: an opportunity for truly personalized treatment. Nat Rev Urol. 2019. doi: 10.1038/s41585-019-0199-x. 
8. Büchser D, Zapatero A, Rogado J, Talaya M, Martín de Vidales C, Arellano R, et al. Long-term Outcomes and Patterns of Failure Following Trimodality Treatment With Bladder Preservation for Invasive Bladder Cancer. Urology. 2019;124:183-90. doi: 10.1016/j.urology.2018.07.058.

9. Solsona E, Iborra I, Collado A, Rubio-Briones J, Casanova J, Calatrava A. Feasibility of radical transurethral resection as monotherapy for selected patients with muscle invasive bladder cancer. J Urol. 2010;184(2):47580. doi: 10.1016/j.juro.2010.04.008.

10. Korpics MC, Block AM, Martin B, Hentz C, Gaynor ER, Henry E, et al. Concurrent chemotherapy is associated with improved survival in elderly patients with bladder cancer undergoing radiotherapy. Cancer. 2017;123(18):3524-31. doi: 10.1002/cncr.30719.

11. Bolenz C, Hautmann RE. Surgical treatment of bladder cancer: advances made in the past 50 years. Aktuelle Urol. 2019. doi: 10.1055/ a-0884-2792.
12. Hampson A, Vincent A, Dasgupta P, Vasdev N. Radical cystectomy complications and perioperative mortality. BJU Int. 2019;124(1):3-4. doi: 10.1111/bju.14718.

13. Coughlin GD, Youl PH, Philpot S, Wright MJ, Honore M, Theile DE, et al. Outcomes following radical cystectomy: a population-based study from Queensland, Australia. ANZ J Surg. 2019;89(6):752-7. doi: 10.1111/ans.15259.

14. Stein JP, Skinner DG. Radical cystectomy for invasive bladder cancer: long-term results of a standard procedure. World J Urol. 2006;24(3):296304. doi: 10.1007/s00345-006-0061-7.

15. Hautmann RE, de Petriconi RC, Volkmer BG. 25 years of experience with 1,000 neobladders: long-term complications. J Urol. 2011;185(6):2207-12. doi: 10.1016/j.juro.2011.02.006.

Надійшла 07.06.19 